Halef Okan Doğan*, Serkan Bolat, Seyit Ali Büyüktuna, Rağıp Sarıismailoğlu, Nazım Çetinkaya, Kübra Doğan, Mürşit Hasbek and Halil Çaylak

\title{
The use of laboratory parameters and computed tomography score to determine intensive care unit requirement in COVID-19
}

\section{[COVID-19 hastalarinda laboratuvar parametreleri ve bilgisayarli tomografi skorunun yoğun bakim gereksiniminin belirlenmesinde kullanımı]}

https://doi.org/10.1515/tjb-2020-0359

Received August 26, 2020; accepted December 26, 2020;

published online February 3, 2021

\section{Abstract}

Objectives: It is vital to determine the intensive care unit (ICU) requirement at an early stage to reduce the mortality rate in COVID-19 patients. The aim of the study was to find reliable predictive markers to determine the ICU requirement.

Methods: We retrospectively reviewed the clinical and laboratory records of 151 COVID-19 patients. The predictive abilities of biochemical parameters and computed tomography (CT) score were evaluated to determine of ICU requirement.

*Corresponding author: Dr. Halef Okan Doğan, Department of Biochemistry, Medical Faculty, Sivas Cumhuriyet University, Sivas, Turkey, Phone: +903462191010/1377, E-mail: halefokan@gmail.com. https://orcid.org/0000-0001-8738-0760

Serkan Bolat, Department of Biochemistry, School of Medicine, University of Sivas Cumhuriyet, Sivas, Turkey

Seyit Ali Büyüktuna, Department of Infectious Diseases, School of Medicine, University of Sivas Cumhuriyet, Sivas, Turkey

Rağıp Sarıismailoğlu, Department of Infectious Disease, Sivas Numune Hospital, Sivas, Turkey

Nazım Çetinkaya and Halil Çaylak, Department of Radiology, Sivas Numune Hospital, Sivas, Turkey

Kübra Doğan, Department of Biochemistry, Sivas Numune Hospital, Sivas, Turkey

Mürşit Hasbek, Department of Microbiology, School of Medicine, University of Sivas Cumhuriyet, Sivas, Turkey
Results: The area under curve (AUC) values for procalcitonin, D-Dimer, $\mathrm{C}$ reactive protein (CRP), glucose, lactate dehydrogenase (LDH) and CT score were found higher than those for other parameters in the prediction of ICU requirement. The negative predictive values of these markers were higher than their positive predictive values. CT score was found to be highly correlated with fibrinogen and CRP. The glucose levels [odd ratio (OR): 95\% CI; 1.07, p-value: 0.014] and CT score [OR: $95 \%$ CI; 1.05, p-value: 0.022 ] were associated with ICU requirement in COVID-19 patients.

Conclusions: CT score, procalcitonin, D-Dimer, CRP, glucose, and LDH are potential predictors to rule out ICU requirement on hospital admission. Fibrinogen and CRP can be used to follow up and predict lung damages in patients with COVID-19.

Keywords: clinical chemistry; computed tomography; COVID-19; intensive care unit; predictive marker.

öz

Amaç: COVID-19 hastalarında ölüm oranını azaltmak için yoğun bakım ünitesi (YBÜ) ihtiyacınının erken dönemde belirlenmesi hayati önem taşır. Çalışmanın amacı, YBÜ gereksinimini belirlemek için güvenilir belirteçler bulmaktı. Gereç ve Yöntem: 151 COVID-19 hastasının klinik ve laboratuvar kayıtlarını geriye dönük olarak inceledik. Biyokimyasal parametrelerin ve bilgisayarlı tomografi (BT) skorunun YBÜ ihtiyacının belirlemesindeki tahmin gücü değerlendirildi.

Bulgular: Yoğun bakım ünitesi gereksiniminin öngörülmesinde prokalsitonin, D-Dimer, C reaktif protein (CRP), 
glukoz, laktat dehidrojenaz (LDH) ve BT skoru için eğri altı alan (AUC) değerleri diğer parametrelere göre daha yüksek bulundu. Bu belirteçlerin negatif tahmin değerleri, pozitif tahmin değerlerinden daha yüksekti. BT skorunun fibrinojen ve CRP ile yüksek oranda korelasyonlu olduğu bulundu. Glikoz seviyeleri [odd ratio (OR): CI 95\%; 1.07, p-değeri: 0.014] ve CT skoru [OR: CI 95\%; 1.05, p değeri: 0.022] COVID-19 hastalarında YBÜ gereksinimi ile ilişkilendirildi.

Sonuç: CT skoru, prokalsitonin, D-Dimer, CRP, glukoz ve LDH, hastaneye yatışta YBÜ gereksinimini dışlamak için potansiyel prediktörlerdir. Fibrinojen ve CRP, COVID-19 hastalarında akciğer hasarlarını takip etmek ve tahmin etmek için kullanılabilir.

\section{Introduction}

Coronaviruses (CoV) are a large family of viruses, which cause severe respiratory infections such as Severe Acute Respiratory Syndrome (SARS) and Middle East Respiratory Syndrome (MERS). A novel coronavirus related infection, Coronavirus disease 2019 (COVID-19), was identified in the city of Wuhan, China, at the end of December 2019 [1]. The World Health Organization (WHO) documented that COVID-19 was seen in 216 countries worldwide and is now accepted as a pandemic. Since 31 December 2019 and as of 06 August 2020, a total of 18,575,326 confirmed cases and 701,754 confirmed deaths were reported by WHO [2]. Although damage can also occur in the different parts of the body including the heart, liver and kidneys, main organs affected by COVID-19 are the lungs. The most common clinical symptoms of patients with COVID-19 are fever (98\%), cough (76\%), shortness of breath (55\%) and myalgia (44\%). Therefore respiratory tract infection related symptoms and signs are the typical findings of patients [3-5].

Despite the fact that the mortality rate varies significantly by country, it has been reported to reach $15.2 \%$ [6]. People over the age of 60 and those with comorbidities such as high blood pressure, kidney disease, or diabetes are at a higher risk of developing the severe disease [3]. Approximately 5\% of COVID-19 patients need treatment in an intensive care unit (ICU) or mechanical ventilation [7]. As of 30 August 2020, 269,550 laboratory-confirmed cases and 6,326 deaths due to COVID-19 have been reported in Turkey. The death rate of all confirmed cases was $2.35 \%$, total number of hospitalizations was 141,503 and intubated patient rate of all confirmed cases were $4.15 \%$ [8]. This fact has brought new challenges to the healthcare system, such as regulation of critical care bed capacity and staff management. The lack of prediction models and effective, specific and proven vaccine or antiviral therapy are other problems related to the disease [9-12]. Thus, it is vital to determine the ICU requirement at an early stage to reduce the mortality rate, the burden of the disease and progression to multiorgan failure. Reliable predictive markers can also allow us to manage the health care system more effectively.

Various clinical laboratory tests and chest computed tomography (CT) are used to diagnose and monitor of COVID-19 patients. Clinical laboratory tests can be divided three groups including serologic, molecular and biochemical tests according to their roles in COVID-19. While serologic and molecular tests are used to diagnose of the disease and assessment of immunity, biochemical tests are used to monitor of the patients. Although, the diagnosis is performed by real time polymerase chain reaction (RT-PCR) and chest CT finding, false positive and false negative results can be observed in RT-PCR. Testing time, targeting gene, test performance, contamination and specimen type are the main that affect RT-PCR performance [13]. Even though CT is another diagnostic tool, findings need to be differentiated from other pathologies that cause similar CT images. Therefore results should be integrated with clinical data [14].

In the present study, we retrospectively reviewed the hospital admission levels of biochemical markers and chest CT findings of COVID-19 patients to find reliable predictive markers for the determination of ICU requirement at an early stage. We also investigated the relationship between biomarkers and radiologic patterns. However, previous studies evaluated the changes of laboratory markers and CT score in COVID-19, little is known about their cut-off values and statistical diagnostic measurements to determine ICU requirement at an early stage in COVID-19 patients. It is thought that this study provides an exciting opportunity to advance existing knowledge regarding the use of laboratory parameters and CT score to determine ICU requirement in COVID-19 patients.

\section{Materials and methods}

\section{Patients}

Blood samples were sent by physicians from COVID clinics. All patients were admitted to Sivas Numune Hospital, Turkey. The clinical characteristics, hematological, biochemical and immunological biomarkers and CT findings of the patients were recorded at the time of hospital admission. Investigated laboratory parameters were given in 
Figure 1. The patients were classified according to the ICU admission and these variables were then evaluated in terms of their predictive roles for ICU requirement. Epidemiological history, clinical manifestations, laboratory findings and RT-PCR (Bioeksen, Istanbul, Turkey), (Rotor-Gene Q, QIAGEN, Hilden, Germany) systems were used to confirm COVID-19 infection. RT-PCR detection of COVID-19 was performed from nasopharyngeal and oropharyngeal swabs. A total of 20 patients were admitted to ICU and 131 patients were discharged without ICU admittance. Of the total patients, $92(61 \%)$ were reported as having $\geq 1$ comorbidity: 57 (38\%), 36 (24\%), $12(8 \%)$, $11(7 \%), 7$ (5\%), 6 (4\%), 1 (0.7\%), $1(0.7 \%), 1(0.7 \%), 1(0.7 \%)$ reported hypertension, diabetes mellitus, hypothyroidism, chronic obstructive pulmonary disease, coronary artery disease, asthma, Familial Mediterranean Fever, rheumatoid arthritis, chronic kidney disease and colon cancer, respectively. The ICU requirements and discharge criteria were determined according to the Turkish Ministry of Health COVID-19 guidelines [15].

ICU admission was indicated with one of the following conditions; (i) dyspnea and respiratory distress (ii) respiratory rate $>30 / \mathrm{min}$ (iii) partial oxygen pressure/fraction of inspired oxygen $<300$ (iv) hypotension (v) acute renal failure, acute increase in liver function tests, confusion, acute bleeding diathesis (vi) higher troponin levels and arrhythmia (vii) lactate levels $>2 \mathrm{mmol}$ (viii) dermal pathologies including prolonged capillary refill and cutis marmorata. The discharge criteria were: (i) afebrile for $>3$ days (ii) significantly improved respiratory symptoms (iii) negative COVID-19 nucleic acid tests. This study was approved by the Local Ethics Committee (decision number: 2020-05/01). The present study performed under the ethical standards laid down in the 1964 Declaration of Helsinki and its later amendments.

\section{Biochemical analysis}

Serum procalcitonin measurements were performed by using the electrochemiluminescent immunoassay method (Roche Cobas e601, Mannheim, Germany). Serum glucose, urea, creatinine, aspartate aminotransferase (AST), alanine aminotransferase (ALT), total bilirubin (Tbil), direct bilirubin (Dbil), lactate dehydrogenase (LDH), phosphorus (P), calcium (Ca) and albumin levels were measured using colorimetric methods (Roche Cobas c702, Mannheim, Germany). Sodium $(\mathrm{Na})$, potassium $(\mathrm{K})$ and chloride $(\mathrm{Cl})$ levels were measured using the ion selective electrode method (Roche Cobas c702, Mannheim, Germany). Complete blood count analysis was performed using

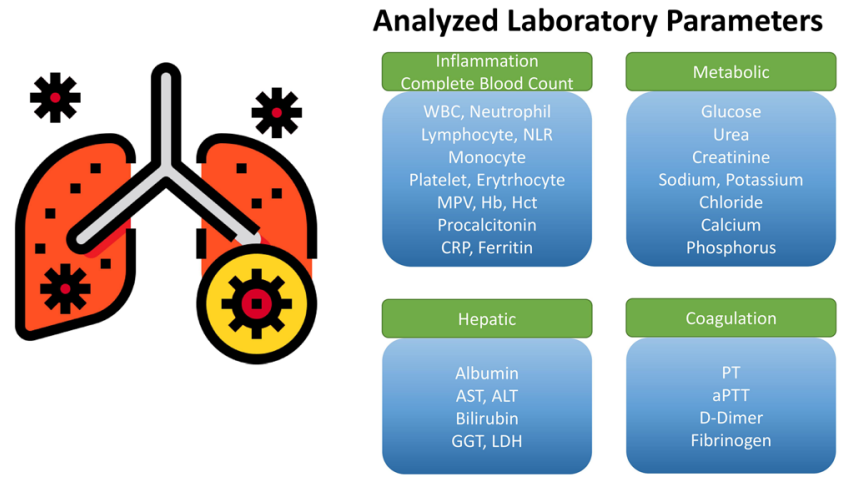

Figure 1: Analyzed laboratory parameters. an autoanalyzer (Sysmex XN1000, Japan). C-reactive protein (CRP) and D-Dimer measurements were performed using the turbidimetric method (Roche Cobas c702, Mannheim, Germany). Fibrinogen, prothrombin time (PT) and activated partial thromboplastin time $\mathrm{a}(\mathrm{PTT})$ values were detected using a coagulation autoanalyzer (Stago Compact Max3, France).

\section{Chest CT image acquisition}

All patients with symptoms suggestive of COVID-19 underwent Chest CT imaging on a 16-detector CT scanner (Alexion; Toshiba or Aquillion; Toshiba). CT images were obtained during a single inspiratory phase in the supine position without contrast medium injection. CT scan parameters were tube voltages $120 \mathrm{KVp}$ with automatic tube current modulation, rotation time $0.5 \mathrm{~s}$ (Aquillion; Toshiba) $-0.75 \mathrm{~s}$ (Alexion; Toshiba), and pitch factor 0.938. Images of $1 \mathrm{~mm}, 3$ and $5 \mathrm{~mm}$ thickness were reconstructed and stored in the PACS system.

\section{Chest CT severity score evaluation}

According to the chest CT severity score in this study, 18 lung segments were considered as 20 segmental parts. The apicoposterior segment of the left upper lobe was divided as apical and posterior segmental parts and the anteromedial basal segment of the left lower lobe was divided as anterior and medial basal segmental parts. Each part was assessed for the degree of involvement as lung opacification and a score of 0 indicated $0 \%$ involvement, a score of $1,<5 \%$ involvement, a score of 2 , 5-25\% involvement, a score of 3, 26-49\% involvement, a score of 4 , $50-75 \%$ involvement, and a score of $5,>75 \%$ involvement. The total severity score was obtained from the total of each of the 20 segmental parts and ranged from 0 to 100 . All CT images were independently reviewed by two board certified general radiologists with eight years of experience, who were blinded to the clinical data and a decision was made by consensus.

\section{Statistical analysis}

The conformity of the data to normal distribution was evaluated using a histogram, $q-q$ graphs and the D'Agostino \& Pearson normality test. The Student's $t$-test, Mann-Whitney $U$-test, One way ANOVA and Kruskal Wallis were applied for between-group comparisons. Correlations between quantitative data were assessed using the Spearman test. Univariate and multiple binary logistic regression analysis were performed in order to identify the factors related with the intensive care unit requirement in COVID-19 patients. Considering the sample size of the study and the missing values of the data, significant variables at $\mathrm{p}<0.01$ in univariate analysis were included into multiple model and forward elimination was applied with likelihood ratio statistic to identify the independent risk factors. After variable selection, a fine tuning was performed to detect the final model. Odds ratios were calculated with $95 \%$ confidence intervals. Hosmer-Lemeshow test was applied to assess the calibration of logistic regression models. Receiver operating characteristic (ROC) curves were plotted for the values of biomarker and CT scores to detect the predictive performance in the determination of ICU requirement. Sensitivity, specificity, positive predictive value (PPV), negative predictive value (NPV) and are under curve (AUC) values were calculated. Categorical variables were compared using the Chi-square test or Fisher exact test for small 
samples. Analyses were conducted using R 3.3.0 (http://www.rproject.org) and easyROC softwares. A p value less than 5\% was considered as statistically significant.

\section{Results}

A retrospective review was made of the records of 151 COVID-19 patients (mean age, 51 years; range, 18-90 years), comprising 73 males (mean age, 50 years; range, 18-87 years) and 78 females (mean age, 52 years; range, 19-90 years) from March 2020 to May 2020. The female/male ratio was 1.06. The median CT scores were found as 33 (15-49) and $1(0-16)$ for ICU-patients and non-ICU patients, respectively. Symptoms and medications of the study groups were given in Table 1. Higher procalcitonin, urea, glucose, LDH, creatinine, CRP, WBC, neutrophil, PT, a(PTT), D-Dimer, fibrinogen as well as lower Ca and albumin levels were determined in patients admitted to ICU than in patients without ICU admission. The comparisons of the laboratory parameters between the COVID-19 patients with and without ICU admission are shown in Table 2. ROC analyses were applied to CT scores, procalcitonin, glucose, urea, creatinine, $\mathrm{LDH}, \mathrm{Ca}$, albumin, $\mathrm{Na}, \mathrm{Cl}, \mathrm{CRP}$, ferritin, WBC, neutrophil, lymphocyte, MPV, D-Dimer, fibrinogen aPTT, ALT, AST and LDH variables to discriminate the need for ICU. Areas under curves (AUC) values were shown in Figure 2. The AUC values for procalcitonin, D-Dimer, glucose, CT score and CRP were higher than those for other parameters (Table 3). The Hosmer-Lemeshow test resulted as $\chi^{2}=5.598, p=0.692$. This result revealed the appropriateness of the built multiple binary logistic regression model in order to predict the intensive care unit requirement in COVID-19 patients. The glucose levels $>114 \mathrm{mg} / \mathrm{dL}$ [odd ratio (OR): CI 95\%; 1.07 (1.01-1.13), p-value: 0.014] and CT score $>15$ [odd ration (OR): CI 95\%; 1.05 (1.01-1.09), p-value: 0.022] were associated with ICU requirement in COVID-19 patients (Table 4). A statistically significant correlation was determined between CT score and D-Dimer ( $\mathrm{p}<0.001, \mathrm{r}=0.615)$, fibrinogen $(\mathrm{p}<0.001, \mathrm{r}=0.777)$ procalcitonin $(\mathrm{p}<0.001$, $\mathrm{r}=0.675), \operatorname{CRP}(\mathrm{p}<0.001, \mathrm{r}=0.749)$, ferritin $(\mathrm{p}=0.01, \mathrm{r}=0.685)$ lymphocyte $(\mathrm{p}<0.001, \mathrm{r}=-0.327)$, glucose $(\mathrm{p}<0.001, \mathrm{r}=0.507)$, urea $(\mathrm{p}=<0.001, \mathrm{r}=0.335)$, creatinine $(\mathrm{p}=0.01, \mathrm{r}=0.258), \mathrm{LDH}$ $(\mathrm{p}<0.001, \mathrm{r}=0.527), \mathrm{Ca}(\mathrm{p}<0.001, \mathrm{r}=-0.560)$, AST $(\mathrm{p}<0.001$, $\mathrm{r}=0.426), \quad \mathrm{P} \quad(\mathrm{p}=0.02, \quad \mathrm{r}=-0.245), \quad$ albumin $\quad(\mathrm{p}<0.001$, $\mathrm{r}=-0.628)$, sodium $(\mathrm{p}<0.001, \mathrm{r}=-0.296)$, chloride $(\mathrm{p}=0.01$, $\mathrm{r}=-0.247), \mathrm{PT}(\mathrm{p}=0.01, \mathrm{r}=0.263)$ values. No correlations were detected between other clinical chemistry markers and the CT score. A heatmap correlation matrix is shown in Figure 3. Higher procalcitonin, glucose, urea, creatinine, AST, LDH, $\mathrm{CRP}$, ferritin, platelet, PT, D-Dimer and fibrinogen values as well as lower albumin, calcium and lymphocyte levels were determined in patients with abnormal chest findings including ground glass opacity (GGO), consolidation and crazy paving pattern compared with patients with normal chest CT findings. The comparisons of the biochemical values of patients according to the presence of GGO, consolidation and crazy paving pattern were shown in Table 5. Comparisons of the biochemical values of the patients according to the different chest CT findings are given in the supplementary material (supplementary material 1).

\section{Discussion}

The contagiousness of COVID-19 is higher than other coronavirus infections. Thus, the disease caught the whole world unprepared. Determination of ICU requirement at an early stage is so important considering the management of the patients and healthcare system. To date, several previous studies evaluated the different routine clinical chemistry markers and computed tomography findings to show the difference between severe and non-severe cases. In those studies limited data were reported regarding the cut-off values and the performance characteristics including AUC, negative (NPV) and positive predictive values (PPV) of these parameters. Besides, little is known about the relationship between biochemical markers and

Table 1: Symptoms and medications of the study groups.

\begin{tabular}{|c|c|c|c|}
\hline & $\begin{array}{l}\text { ICU positive } \\
(n: 20)\end{array}$ & $\begin{array}{l}\text { ICU negative } \\
\text { (n: 131) }\end{array}$ & $\mathbf{p}$ \\
\hline \multicolumn{4}{|l|}{ Symptoms } \\
\hline Fever & $10(50)$ & $43(35.53)$ & $=0.216$ \\
\hline Sore throat & $1(5)$ & $26(21.48)$ & $=0.082$ \\
\hline Fatigue & $3(15)$ & $51(42.14)$ & $=0.020$ \\
\hline Headache & None & $10(8.26)$ & $=0.182$ \\
\hline Cough & $13(65)$ & $62(51.23)$ & $=0.253$ \\
\hline Dyspnea & $17(85)$ & $25(20.66)$ & $<0.0001$ \\
\hline Taste/smell abnormalities & None & $3(2.47)$ & $=0.476$ \\
\hline Stomachache & $2(10)$ & $9(7.43)$ & $=0.088$ \\
\hline Diarrhea & $3(15)$ & $6(4.95)$ & $=0.692$ \\
\hline Nausea & $2(10)$ & $10(8.26)$ & $=0.796$ \\
\hline \multicolumn{4}{|l|}{ Medications } \\
\hline Hydroxychloroquine & $20(100)$ & $120(99.17)$ & $=0.683$ \\
\hline Oseltamivir & $16(80)$ & $64(52.89)$ & $=0.023$ \\
\hline Azitromisin & $1(5)$ & $40(33.05)$ & $<0.0001$ \\
\hline Moxifloxacin & $19(95)$ & $29(23.96)$ & $<0.0001$ \\
\hline Lopinavir & $5(25)$ & None & $<0.0001$ \\
\hline Tazocin & $13(65)$ & None & $<0.0001$ \\
\hline Favipiravir & $13(65)$ & $4(3.30)$ & $<0.0001$ \\
\hline Tocilizumab & $2(10)$ & None & $<0.0001$ \\
\hline Plasma exchange & $3(15)$ & None & $<0.0001$ \\
\hline
\end{tabular}


Table 2: Comparison of biochemical values of patients according to intensive care admission.

\begin{tabular}{|c|c|c|c|c|}
\hline \multirow[t]{2}{*}{ Parameters } & \multirow[t]{2}{*}{ \# Of patients (yes/no) } & \multicolumn{2}{|c|}{ ICU admission } & \multirow[t]{2}{*}{$\mathrm{p}$} \\
\hline & & Yes & No & \\
\hline Procalcitonin, $\mathrm{ng} / \mathrm{mL}$ & $14 / 69$ & $0.18(0.11-0.57)$ & $0.078(0.04-0.10)$ & $<0.0001$ \\
\hline Glucose, $\mathrm{mg} / \mathrm{dL}$ & $18 / 133$ & $167.9(121.8-283.5)$ & $93.30(86.35-111.7)$ & $<0.001$ \\
\hline Urea, mg/dL & $18 / 133$ & $64.25(42.35-118.8)$ & $28.90(24.40-39.10)$ & $<0.0001$ \\
\hline Creatinine, $\mathrm{mg} / \mathrm{dL}$ & $20 / 131$ & $1.27(0.8450-1.823)$ & $0.84(0.70-0.97)$ & $<0.0001$ \\
\hline AST, U/L & $20 / 130$ & $30.10(19.55-53.05)$ & $24.30(17.38-31.18)$ & $=0.06$ \\
\hline ALT, U/L & $13 / 106$ & $60.00(46.00-74.50)$ & $71.50(52.75-86.00)$ & $=0.162$ \\
\hline TBil, mg/dL & $19 / 122$ & $0.52(0.38-0.68)$ & $0.44(0.33-0.57)$ & $=0.175$ \\
\hline $\mathrm{DBil}, \mathrm{mg} / \mathrm{dL}$ & $19 / 123$ & $0.20(0.12-0.28)$ & $0.16(0.11-0.22)$ & $=0.241$ \\
\hline $\mathrm{LDH}, \mathrm{U} / \mathrm{L}$ & $13 / 95$ & $367.00(258.00-541.50)$ & $219.00(184.00-279.00)$ & $<0.001$ \\
\hline $\mathrm{P}, \mathrm{mg} / \mathrm{dL}$ & $18 / 87$ & $3.26(2.89-4.53)$ & $3.73(3.230-4.20)$ & $=0.174$ \\
\hline Calcium, mg/dL & $20 / 125$ & $8.36(7.98-9.08)$ & $9.22(8.820-9.70)$ & $<0.001$ \\
\hline Albumin, $\mathrm{g} / \mathrm{dL}$ & $17 / 121$ & $3.80(3.66-4.12)$ & $4.38(4.03-4.70)$ & $<0.0001$ \\
\hline *Sodium, mmol/L & $20 / 131$ & $136.9 \pm 4.54$ & $139.2 \pm 3.257$ & $=0.0052$ \\
\hline *Potassium, mmol/L & $19 / 130$ & $4.42 \pm 0.52$ & $4.35 \pm 0.39$ & $=0.517$ \\
\hline${ }^{\star}$ Chloride, $\mathrm{mmol} / \mathrm{L}$ & $18 / 125$ & $98.79 \pm 4.58$ & $101.1 \pm 3.581$ & $=0.014$ \\
\hline $\mathrm{CRP}, \mathrm{mg} / \mathrm{dL}$ & $20 / 130$ & $9.00(4.38-17.72)$ & $0.79(0.17-4.19)$ & $<0.0001$ \\
\hline Ferritin, $\mathrm{ng} / \mathrm{mL}$ & $8 / 74$ & $696.00(222.80-791.10)$ & $175.00(48.75-354.60)$ & $=0.0036$ \\
\hline WBC $\left(10^{3} / \mu \mathrm{lt}\right)$ & $20 / 131$ & $8.66(6.14-10.81)$ & $6.01(4.47-7.80)$ & $=0,0009$ \\
\hline Neutrophil $\left(10^{3} / \mu \mathrm{lt}\right)$ & $20 / 131$ & $6.59(4.09-8.30)$ & $3.78(2.64-5.060)$ & $<0,0001$ \\
\hline Lymphocyte $\left(10^{3} / \mu \mathrm{lt}\right)$ & $20 / 131$ & $1.47(0.71-1.68)$ & $1.61(1.07-2.17)$ & $=0.0328$ \\
\hline NLR & $20 / 131$ & $2.18(1.56-3.56)$ & $4.28(2.99-10.25)$ & $<0.0001$ \\
\hline Monocyte $\left(10^{3} / \mu \mathrm{lt}\right)$ & $20 / 131$ & $0.52(0.37-0.76)$ & $0.45(0.35-0.64)$ & $=0.282$ \\
\hline${ }^{*} \mathrm{RBC}\left(10^{6} / \mu \mathrm{lt}\right)$ & $20 / 131$ & $4.80 \pm 0.64$ & $4.88 \pm 0.58$ & $=0.597$ \\
\hline${ }^{*} \mathrm{Hb}, \mathrm{g} / \mathrm{dL}$ & $20 / 131$ & $13.57 \pm 1.91$ & $13.87 \pm 1.82$ & $=0.486$ \\
\hline *Hct, \% & $20 / 131$ & $41.67 \pm 5.27$ & $41.93 \pm 4.76$ & $=0.819$ \\
\hline *Platelet & $20 / 131$ & $235 \pm 94$ & $234 \pm 74$ & $=0.933$ \\
\hline MPV, $\mathrm{fl}$ & $20 / 131$ & $11.05(10.35 \pm 11.75)$ & $10.30(9.70-10.90)$ & $=0.0042$ \\
\hline PT, sec & $19 / 127$ & $15.60(14.40-31.60)$ & $14.20(13.50-15.00)$ & $=0.0014$ \\
\hline *a(PTT) (sec) & $19 / 127$ & $31.37 \pm 3.35$ & $30.76 \pm 5.95$ & $=0.664$ \\
\hline D-dimer, $\mathrm{ng} / \mathrm{mL}$ & $19 / 124$ & $1,239(423-3,271)$ & $244.00(155.00-407.00)$ & $<0.0001$ \\
\hline Fibrinogen, mg/dL & $13 / 123$ & $477.00(375.00-677.00)$ & $396.00(291.00-508.00)$ & $=0.005$ \\
\hline
\end{tabular}

AST, Aspartate amino transferase; ALT, Alanin amino transferase; a(PTT), Activated partial thromboplastin time; CRP, C reactive protein; Dbil, Direct bilirubin; Hb, Hemoglobin; Hct, Hematocrit; MPV, Mean platelet volüme; NLR, Neutrophil-lymphocyte ratio; P, Phosphorus; PT, prothrombin time; RBC, Red blood cell; TBil, Total bilirubin; WBC, White blood cells. Results were given as *mean \pm standard deviation or median (1st and third quartiles). A value of $p<0.05$ was considered statistically significant.

radiologic patterns. In the current study, the AUC values for procalcitonin, D-Dimer, CRP, glucose, LDH and CT score were found higher in the prediction of ICU requirement. The negative predictive values of these parameters were higher than positive predictive values. We found higher CRP and fibrinogen levels in patients with abnormal chest findings pattern compared to patients with normal chest CT findings. Finally, the CT score was found correlated with CRP and fibrinogen.

In a meta-analysis by Henry et al. [16] increased levels of WBC, ferritin, CRP, procalcitonin, D-Dimer, PT, AST and ALT and decreased levels of lymphocyte, platelet and albumin were determined in COVID-19 patients with severe and fatal disease compared to non-severe disease and survivors. Chen et al. [17] found increased neutrophil,
D-Dimer, AST, ALT, LDH, procalcitonin, CRP and ferritin levels in COVID-19 patients. A report by Lippi et al. [18] indicated that increased levels of D-Dimer, AST, ALT, LDH, procalcitonin, CRP and ferritin were associated with unfavorable progression of COVID-19. Huang et al. [19] showed that the AST, PT and D-Dimer levels of ICU patients on admission were higher than those of non-ICU patients. Zhou et al. [20] found higher WBC, ALT, LDH, PT, D-Dimer, and ferritin levels and decreased lymphocyte, platelet and albumin levels in survived COVID-19 patients than in non-survived patients. Zhang et al. [21] detected lower lymphocyte levels in severe cases compared to non-severe cases. Decreased levels of $\mathrm{Ca}, \mathrm{Na}$ and $\mathrm{K}$ and were detected in severe COVID-19 patients [22]. The prevalence of elevated serum creatinine and urea levels was reported as 14.4 


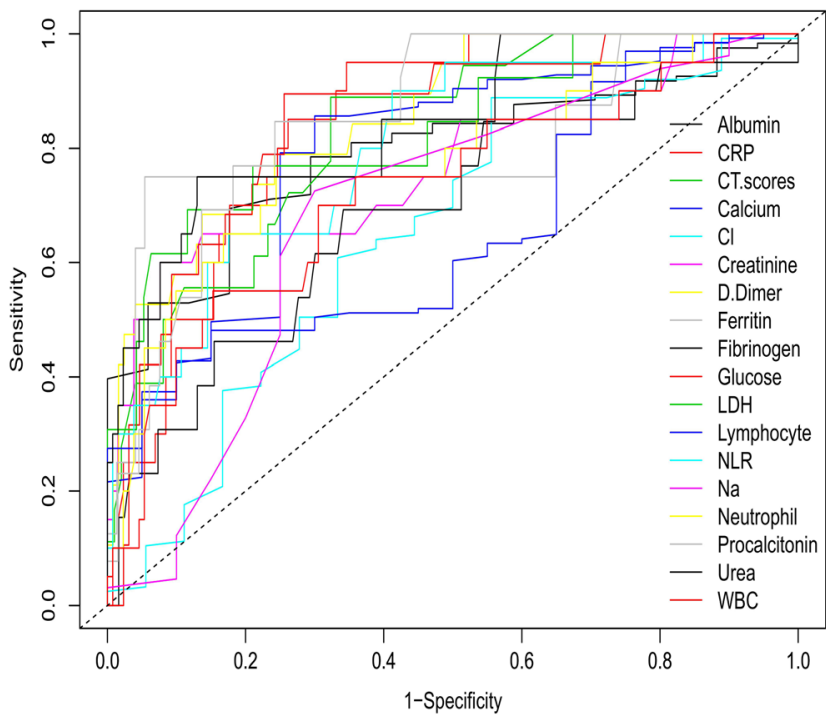

Figure 2: Diagnostic performances of different variables in the prediction of intensive care unit requirement.

and $13.1 \%$, respectively in COVID-19 patients [23]. Our findings are in accordance with the previous studies. The levels of positive acute phase reactants increase during inflammation. Fibrinogen, CRP, procalcitonin and ferritin are well known positive acute phase reactant [24]. In the current study, the levels of procalcitonin, CRP, ferritin, WBC, D-Dimer and fibrinogen were found to be higher in ICU patients compared non-ICU patients. Thus, we think that higher inflammation state causes more elevation in fibrinogen and its degradation product, D-Dimer, in ICU patients compared to non ICU patients. We also speculate that the levels of procalcitonin, CRP, ferritin, WBC, D-Dimer and fibrinogen can be used to estimate inflammatory status and prognosis of COVID-19 patients.

In our study we determined higher serum glucose levels in ICU patients than non-ICU patients. Besides we determined an association between ICU requirement and glucose levels. The percentage of diabetic patients in ICU and non ICU groups were 55 and 19\%, respectively in this study. Therefore, we think that higher glucose levels in ICU patients may be related with higher percentages of diabetes mellitus in ICU patents than non ICU patients. Significantly higher values of serum glucose were reported in non-survived COVID-19 patients [25]. Precipitated diabetic ketoacidosis by COVID-19 has been reported in a patient with newly diagnosed diabetes mellitus [26]. Prolonged length of hospital stay and increased mortality due to induced diabetic ketoacidosis have been reported in patients with COVID-19 [27]. The triglyceride-glucose index, which is a reliable surrogate marker of insulin

Table 3: Statistical diagnostic measurements of clinical chemistry markers and computational tomography score levels in discriminating ICU requirement.

\begin{tabular}{|c|c|c|c|c|c|c|c|}
\hline \multirow[t]{2}{*}{ Variables } & \multirow[t]{2}{*}{ Cut-off values } & \multicolumn{4}{|c|}{ Statistical diagnostic measurement } & \multicolumn{2}{|c|}{ ROC curve statistic } \\
\hline & & SEN $(95 \% \mathrm{Cl})$ & SPE $(95 \% \mathrm{Cl})$ & PPV $(95 \% \mathrm{Cl})$ & NPV $(95 \% \mathrm{Cl})$ & AUC & \\
\hline T scores & $>15$ & $0.89(0.65-0.99)$ & $0.68(0.58-0.77)$ & $0.33(0.24-0.82)$ & $0.97(0.89-0.98)$ & $0.83(0.73-0.92)$ & $<0.000$ \\
\hline rocalcitonin, $\mathrm{ng} / \mathrm{mL}$ & $>0.109$ & $0.85(0.55-0.98)$ & $0.76(0.64-0.86)$ & $0.41(0.28-0.87)$ & $0.96(0.85-0.98)$ & $0.86(0.76-0.95)$ & $<0.0001$ \\
\hline Glucose, $\mathrm{mg} / \mathrm{dL}$ & $>114$ & $0.90(0.67-0.99)$ & $0.74(0.66-0.82)$ & $0.34(0.26-0.82)$ & $0.98(0.92-0.99)$ & $0.84(0.76-0.93)$ & $<0.0001$ \\
\hline Urea, mg/dL & $>45.7$ & $0.75(0.51-0.91)$ & $0.87(0.80-0.92)$ & $0.47(0.35-0.76)$ & $0.96(0.89-0.98)$ & $0.80(0.66-0.94)$ & $<0.0001$ \\
\hline Creatinin, $\mathrm{mg} / \mathrm{dL}$ & $>1.19$ & $0.60(0.36-0.81)$ & $0.92(0.86-0.96)$ & $0.55(0.39-0.77)$ & $0.94(0.85-0.97)$ & $0.77(0.63-0.90$ & $<0.0001$ \\
\hline $\mathrm{LDH}, \mathrm{U} / \mathrm{L}$ & 15 & $0.69(0.3$ & $0.88(0.80-0.94)$ & $0.45(0.30-0.78)$ & .98) & $0-0.96)$ & $<0.0001$ \\
\hline Calcium, mg/dL & $<8.51$ & $0.70(0.46-0.88)$ & $0.86(0.78-0.91)$ & $0.44(0.32-0.71)$ & $0.95(0.87-0.97)$ & $0.79(0.68-0.90)$ & $<0.0001$ \\
\hline Albumin, $\mathrm{g} / \mathrm{dL}$ & $<4.13$ & $0.82(0.57-0.96)$ & $0.69(0.60-0.78)$ & $0.28(0.20-0.67)$ & $0.97(0.89-0.98)$ & $0.79(0.70-0.88)$ & $<0.0001$ \\
\hline $\mathrm{Na}, \mathrm{m}$ & $>137$ & $0.70(0.46-0.88)$ & $0.73(0.64-0.80)$ & $0.28(0.21-0.55)$ & $0.94(0.85-0.96)$ & $0.69(0.54-0.83)$ & $<0.05$ \\
\hline $\mathrm{Cl}, \mathrm{mmol} / \mathrm{L}$ & $>97$ & $0.44(0.22-0.69)$ & $0.89(0.82-0.94)$ & $0.36(0.25-0.62)$ & $0.92(0.79-0.95)$ & $0.65(0.50-0.80)$ & $<0.05$ \\
\hline $\mathrm{CRP}, \mathrm{mg} / \mathrm{dL}$ & $>2.19$ & $0.95(0.75-1.00)$ & $0.65(0.57-0.74)$ & $0.30(0.23-0.95)$ & $0.99(0.93-0.99)$ & $0.85(0.77-0.92)$ & $<0.0001$ \\
\hline Ferritin, $\mathrm{ng} / \mathrm{mL}$ & $>648$ & $0.75(0.35-0.97)$ & $0.95(0.87-0.99)$ & $0.60(0.36-0.94)$ & $0.97(0.86-0.99)$ & $0.80(0.59-1.02)$ & $<0.01$ \\
\hline WBC $\left(10^{3} / \mu \mathrm{lt}\right)$ & $>8.51$ & $0.55(0.32-0.77)$ & $0.85(0.77-0.90)$ & $0.36(0.25-0.60)$ & $0.93(0.82-0.95)$ & $0.73(0.60-0.85)$ & $<0.001$ \\
\hline Neutrophil $\left(10^{3} / \mu \mathrm{lt}\right)$ & $>4.95$ & $0.75(0.51-0.91)$ & $0.76(0.67-0.83)$ & $0.32(0.24-0.62)$ & $0.95(0.87-0.97)$ & $0.78(0.65-0.90)$ & $<0.0001$ \\
\hline Lymphocyte $\left(10^{3} / \mu \mathrm{lt}\right)$ & $<1.69$ & $0.85(0.62-0.97)$ & $0.48(0.40-0.57)$ & $0.20(0.15-0.57)$ & $0.96(0.86-0.97)$ & $0.66(0.54-0.77)$ & $<0.01$ \\
\hline NLR & $>2.73$ & $0.90(0.68-0.99)$ & $0.59(0.50-0.67)$ & $0.25(0.19-0.75)$ & $0.98(0.90-0.98)$ & $0.80(0.69-0.90)$ & $<0.0001$ \\
\hline MPV, fl & $>10.9$ & $0.55(0.32-0.77)$ & $0.74(0.66-0.81)$ & $0.24(0.18-0.47)$ & $0.92(0.80-0.94)$ & $0.65(0.50-0.80)$ & $<0.05$ \\
\hline D-Dimer, $\mathrm{ng} / \mathrm{mL}$ & $>423$ & $0.79(0.54-0.94)$ & $0.76(0.67-0.83)$ & $0.33(0.25-0.67)$ & $0.96(0.88-0.97)$ & $0.86(0.77-0.94)$ & $<0.0001$ \\
\hline Fibrinogen, $\mathrm{mg} / \mathrm{dL}$ & $>354$ & $1.00(0.75-1.00)$ & $0.43(0.34-0.52)$ & $0.16(0.11-1.00)$ & $1.00(0.93-1.00)$ & $0.73(0.60-0.86)$ & $<0.001$ \\
\hline
\end{tabular}

SEN, Sensitivity SPE, Specificity PPV, Positive predictive value NPV, Negative predictive value AUC, Area under curve ROC, Receiver operating characteristic; CT, Computational tomography; LDH, Lactate dehydrogenase; NLR, Neutrophil-lymphocyte ratio; Na, Sodium; Cl, Chloride; CRP, C-reactive protein; WBC, White blood cells; MPV, Mean platelet volume. A value of $p<0.05$ was considered statistically significant. 
Table 4: Logistic regression analysis results of predicting intensive care unit requirement in COVID-19 patients.

\begin{tabular}{|c|c|c|c|c|}
\hline \multirow[t]{2}{*}{ Variables } & \multicolumn{2}{|c|}{ Univariate } & \multicolumn{2}{|c|}{ Multiple } \\
\hline & OR $(95 \% \mathrm{Cl})$ & $\mathbf{p}$ & OR $(95 \% \mathrm{Cl})$ & $\mathbf{p}$ \\
\hline CT scores & $1.07(1.03-1.12)$ & $<0.001$ & $1.07(1.01-1.13)$ & 0.014 \\
\hline Procalcitonin, ng/mL & $9.14(1.26-66.23)$ & 0.029 & - & - \\
\hline Glucose, $\mathrm{mg} / \mathrm{dL}$ & $1.05(1.02-1.08)$ & 0.003 & 1.05 (1.01-1.09) & 0.022 \\
\hline Urea, mg/dL & $1.08(1.02-1.14)$ & 0.013 & - & - \\
\hline Creatinin, $\mathrm{mg} / \mathrm{dL}$ & $11.81(1.21-115.52)$ & 0.034 & - & - \\
\hline $\mathrm{LDH}, \mathrm{U} / \mathrm{L}$ & $1.02(1.01-1.03)$ & 0.004 & - & - \\
\hline Calcium, mg/dL & $0.22(0.06-0.76)$ & 0.017 & - & - \\
\hline Albumin, $\mathrm{g} / \mathrm{dL}$ & $0.09(0.01-0.57)$ & 0.011 & - & - \\
\hline $\mathrm{Na}, \mathrm{mmol} / \mathrm{L}$ & $0.74(0.59-0.93)$ & 0.010 & - & - \\
\hline $\mathrm{Cl}, \mathrm{mmol} / \mathrm{L}$ & $0.79(0.65-0.95)$ & 0.010 & - & - \\
\hline CRP, mg/dL & $1.15(1.05-1.26)$ & 0.003 & - & - \\
\hline WBC $\left(10^{3} / \mu \mathrm{lt}\right)$ & $1.18(0.98-1.43)$ & 0.084 & - & - \\
\hline Neutrophil $\left(10^{3} / \mu \mathrm{lt}\right)$ & $1.00(0.96-1.04)$ & 0.988 & - & - \\
\hline Lymphocyte $\left(10^{3} / \mu \mathrm{lt}\right)$ & $0.55(0.20-1.55)$ & 0.259 & - & - \\
\hline NLR & $1,231(1.069-1.417)$ & 0.004 & - & - \\
\hline MPV, fl & $1.83(0.86-3.90)$ & 0.117 & - & - \\
\hline D-Dimer, $\mathrm{ng} / \mathrm{mL}$ & $1.01(1.00-1.01)$ & 0.031 & - & - \\
\hline Fibrinogen, $\mathrm{mg} / \mathrm{dL}$ & $1.00(0.99-1.01)$ & 0.096 & - & - \\
\hline
\end{tabular}

OR, Odds ratio; $\mathrm{Cl}$, Confidence interval; CT, Computed tomography; LDH, Lactate dehydrogenase; NLR, Neutrophil-lymphocyte ratio; Na, Sodium; Cl, Chloride; CRP, C-reactive protein; WBC, White blood cell; MPV, Mean platelet volume.

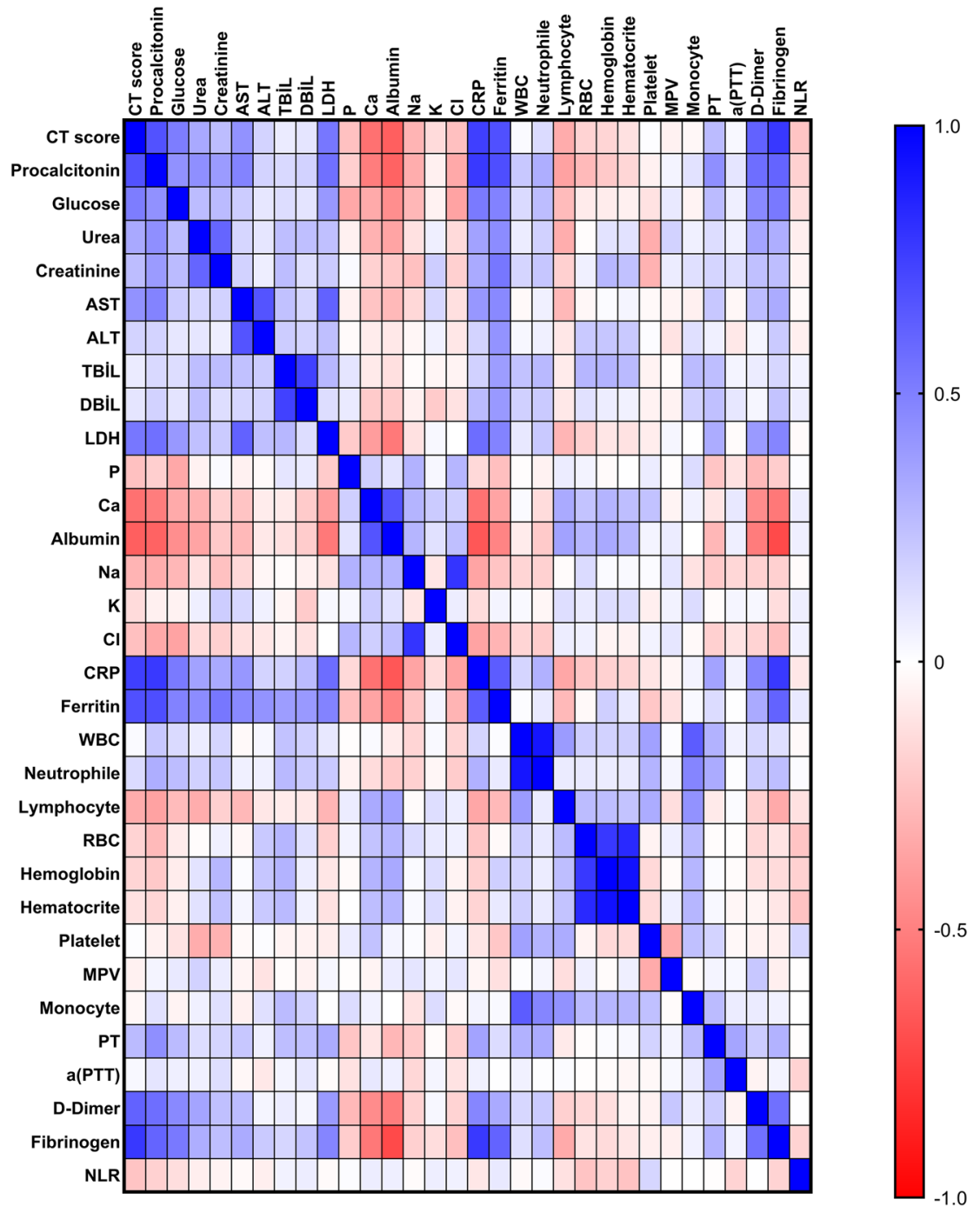

Figure 3: Heatmap correlation matrix between biochemical markers and chest computed tomography score. 
Table 5: Comparison of biochemical values of patients according to chest CT findings.

\begin{tabular}{|c|c|c|c|c|c|c|}
\hline Parameters & $\begin{array}{r}\text { Reference } \\
\text { range }\end{array}$ & $\begin{array}{r}\text { \# Of } \\
\text { patients }\end{array}$ & None & GGO & GGO + CON + CPP & \\
\hline Procalcitonin, ng/mL & $0.5-2$ & $16 / 21 / 11$ & $0.04(0.02-0.06)^{a}$ & $0.08(0.06-0.12)^{a}$ & $0.16(0.07-1.23)^{b}$ & $=0.0027$ \\
\hline Glucose, $\mathrm{mg} / \mathrm{dL}$ & $70-99$ & $31 / 39 / 16$ & $86.00(81.00-101.00)^{\mathrm{a}}$ & $96.70(88.80-125.50)^{b}$ & $137.80(92.18-214.60)^{b}$ & $=0.0002$ \\
\hline Urea, mg/dL & $17-43$ & $32 / 40 / 16$ & $25.50(22.03-33.33)^{\mathrm{a}}$ & $34.45(25.88-43.63)^{b}$ & $40.70(23.28-67.43)^{b}$ & $=0.013$ \\
\hline Creatinine, $\mathrm{mg} / \mathrm{dL}$ & $0.5-1.2$ & $32 / 40 / 16$ & $0.75(0.67-0.92) a$ & $0.89(0.76-1.04) a, b$ & $1.06(0.75-1.67) b$ & $=0.013$ \\
\hline AST, U/L & $0-50$ & $32 / 39 / 16$ & $20.40(15.85-27.43)^{a}$ & $20.60(17.00-32.10)^{a, b}$ & $35.40(23.35-48.33)^{b}$ & $=0.029$ \\
\hline ALT, U/L & $0-50$ & $32 / 40 / 16$ & $18.75(11.83-28.75)$ & $21.70(12.63-38.20)$ & $31.55(12.58-37.08)$ & $=0.516$ \\
\hline TBil, mg/dL & $0.3-1.2$ & $30 / 39 / 14$ & $0.45(0.36-0.60)$ & $0.39(0.30-0.56)$ & $0.52(0.39-0.71)$ & $=0.188$ \\
\hline DBil, mg/dL & $0-0.2$ & $30 / 39 / 14$ & $0.16(0.11-0.20)$ & $0.16(0.12-0.21)$ & $0.15(0.09-0.30)$ & $=0.955$ \\
\hline $\mathrm{LDH}, \mathrm{U} / \mathrm{L}$ & $0-248$ & $24 / 27 / 10$ & $\begin{array}{r}196.00(157.50- \\
253.50)^{\mathrm{a}}\end{array}$ & $\begin{array}{r}205.00(182.00- \\
242.00)^{\mathrm{a}}\end{array}$ & $\begin{array}{r}366.00(284.30- \\
673.80)^{\mathrm{b}}\end{array}$ & $=0.0004$ \\
\hline $\mathrm{P}, \mathrm{mg} / \mathrm{dL}$ & $2.5-4.9$ & $20 / 32 / 12$ & $3.94(3.33-4.26)$ & $3.52(3.10-4.17)$ & $3.67(3.21-4.35)$ & $=0.430$ \\
\hline Calcium, mg/dL & $8.6-10.3$ & $32 / 37 / 16$ & $9.78(9.44-9.88)^{\mathrm{a}}$ & $8.95(8.53-9.32)^{b}$ & $8.78(8.44-9.34)^{b}$ & $<0.0001$ \\
\hline Albumin, $\mathrm{g} / \mathrm{dL}$ & $35-52$ & $30 / 38 / 14$ & $4.71(4.46-4.89)^{\mathrm{a}}$ & $4.30(4.10-4.48)^{b}$ & $3.88(3.69-4.16)^{c}$ & $<0.0001$ \\
\hline *Sodium, mmol/L & $136-145$ & $32 / 40 / 16$ & $139.7 \pm 2.14$ & $138.5 \pm 3.70$ & $137.8 \pm 4.00$ & $=0.058$ \\
\hline${ }^{\star}$ Potassium, mmol/L & $3.5-5.1$ & $32 / 39 / 15$ & $4.47 \pm 0.37$ & $4.36 \pm 0.40$ & $4.45 \pm 0.57$ & $=0.497$ \\
\hline${ }^{\star}$ Chloride, $\mathrm{mmol} / \mathrm{L}$ & $101-109$ & $32 / 38 / 14$ & $101.9 \pm 2.61$ & $100.9 \pm 3.82$ & $99.37 \pm 4.50$ & $=0.090$ \\
\hline $\mathrm{CRP}, \mathrm{mg} / \mathrm{dL}$ & $0-0.5$ & $32 / 40 / 15$ & $0.1(0.07-0.28)^{\mathrm{a}}$ & $1.36(0.45-3.61)^{\mathrm{b}}$ & $6.54(4.50-13.89)^{c}$ & $<0.0001$ \\
\hline Ferritin, $\mathrm{ng} / \mathrm{mL}$ & $20-250$ & $18 / 20 / 8$ & $67.50(13.75-147.80)^{\mathrm{a}}$ & $\begin{array}{r}284.70(87.00- \\
423.20)^{a, b}\end{array}$ & $\begin{array}{r}520.10(439.00- \\
648.80)^{\mathrm{b}}\end{array}$ & $<0.0001$ \\
\hline WBC $\left(10^{3} / \mu \mathrm{lt}\right)$ & $3.2-10.6$ & $32 / 40 / 16$ & $7.70(5.39-8.46)$ & $5.44(4.28-6.98)$ & $7.70(4.45-10.46)$ & $=0.058$ \\
\hline Neutrophil $\left(10^{3} / \mu \mathrm{lt}\right)$ & $1.3-7$ & $32 / 40 / 16$ & $4.27(3.33-5.06)$ & $3.31(2.40-4.48)$ & $5.70(2.57-8.18)$ & $=0.506$ \\
\hline Lymphocyte $\left(10^{3} / \mu \mathrm{lt}\right)$ & $0.8-3.1$ & $32 / 40 / 16$ & $2.11(1.57-2.64)^{\mathrm{a}}$ & $1.56(1.05-2.15)^{\mathrm{b}}$ & $1.58(0.92-1.81)^{b}$ & $=0.0027$ \\
\hline NLR & & $32 / 40 / 16$ & $2.08(1.34-3.68)$ & $1.96(1.56-2.52)$ & $3.46(1.78-5.70)$ & $=0.242$ \\
\hline Monocyte $\left(10^{3} / \mu \mathrm{lt}\right)$ & $0.2-0.9$ & $32 / 40 / 16$ & $0.49(0.38-0.69)$ & $0.44(0.33-0.72)$ & $0.59(0.41-0.78)$ & $=0.537$ \\
\hline${ }^{\star} \mathrm{RBC}\left(10^{6} / \mu \mathrm{lt}\right)$ & $4.7-6.1$ & $32 / 40 / 16$ & $5.01 \pm 0.55$ & $4.90 \pm 0.60$ & $4.66 \pm 0.74$ & $=0.182$ \\
\hline${ }^{\star} \mathrm{Hb}, \mathrm{g} / \mathrm{dL}$ & $13.5-17.5$ & $32 / 40 / 16$ & $14.28 \pm 1.68$ & $14.01 \pm 1.68$ & $13.20 \pm 2.25$ & $=0.148$ \\
\hline${ }^{\star} \mathrm{Hct}, \%$ & $38.5-50$ & $32 / 40 / 16$ & $42.51 \pm 4.34$ & $42.35 \pm 4.62$ & $40.38 \pm 6.03$ & $=0.310$ \\
\hline *Platelet & $150-450$ & $32 / 40 / 16$ & $\begin{array}{r}267.50(190.50- \\
310.80)^{a, b}\end{array}$ & $\begin{array}{r}213.50(165.50- \\
252.30)^{\mathrm{a}}\end{array}$ & $\begin{array}{r}283.50(202.00- \\
351.80)^{\mathrm{b}}\end{array}$ & $=0.010$ \\
\hline MPV, fl & $9.7-11.9$ & $32 / 40 / 16$ & $10.30(9.72-10.85)$ & $10.60(10.00-11.50)$ & $10.15(9.50-11.03)$ & $=0.216$ \\
\hline PT, sec & $12-17$ & $30 / 38 / 16$ & $14.15(13.48-15.10)^{\mathrm{a}}$ & $14.00(13.48-14.73)^{\mathrm{a}}$ & $15.60(14.73-16.28)^{b}$ & $=0.008$ \\
\hline *a(PTT) (sec) & $25-36$ & $30 / 38 / 16$ & $29.85(28.48-33.33)$ & $29.65(28.00-31.35)$ & $31.05(27.85-33.10)$ & $=0.182$ \\
\hline D-dimer, $\mathrm{ng} / \mathrm{mL}$ & $0-500$ & $31 / 38 / 14$ & $158.00(62.00-245.00)$ & $\begin{array}{r}279.50(203.30- \\
425.30)\end{array}$ & $\begin{array}{r}631.00(354.00- \\
1760.00)\end{array}$ & $<0.0001$ \\
\hline Fibrinogen, $\mathrm{mg} / \mathrm{dL}$ & $200-400$ & $32 / 33 / 13$ & $\begin{array}{r}273.00(257.30- \\
308.80)^{\mathrm{a}}\end{array}$ & $\begin{array}{r}396.00(342.50- \\
470.00)^{b}\end{array}$ & $\begin{array}{r}546.00(474.50- \\
688.50)^{c}\end{array}$ & $<0.0001$ \\
\hline
\end{tabular}

GGO, Ground glass opacity; CON, Consolidation; CPP, Crazy paving pattern. AST, Aspartate amino transferase; ALT, Alanin amino transferase; TBil, Total bilirubin; Dbil, Direct bilirubin; CRP, C reactive protein; WBC, White blood cells; RBC, Red blood cell; Hb, Hemoglobin; Hct, Hematocrit; NLR, Neutrophil-lymphocyte ratio; MPV, Mean platelet volume; P, Phosphorus; PT, prothrombin time; a(PTT), Activated partial thromboplastin time. Results were given as *mean \pm standard deviation or median (1st and third quartiles). A value of $p<0.05$ was considered statistically significant.

resistance, has been reported to be closely associated with the severity and morbidity in COVID-19 patients [28]. Our findings support the previous studies that higher glucose levels and diabetes mellitus are related with the severity of the disease in COVID-19 patients. High glucose levels cause an increase in glycated hemoglobin ( $\mathrm{Hb}$ ) level. Glycosylation leads to alteration the structure and oxygen affinity pattern of $\mathrm{Hb}$ and shift the oxygen dissociation curve to the left. These changes cause elevation in oxygen affinity of $\mathrm{Hb}$ and a decrease in oxygen releasing to the peripheral tissues [29]. In line with this literature information and our findings, we propose that increased glycated $\mathrm{Hb}$ level due to high glucose levels and diabetes mellitus may decrease the oxygenation and lead severe cases in COVID-19.

Our results revealed that the top five markers with the highest AUC, specificity and sensitivity values in the determination of ICU requirement were, procalcitonin, D-Dimer, CRP, glucose, and LDH, respectively. As an 
important finding, we also determined that the negative predictive values of these biomarkers were higher than positive predictive values. In the light of these findings we think that these markers can be used to rule out serious cases rather than rule in. Besides, the cut off values were within the reference ranges in terms of procalcitonin, CRP and D-Dimer. Thus, clinicians should be aware to the changes within the reference values.

As the lungs are the main organs affected by COVID-19, chest CT is strongly recommended in suspected COVID-19 cases for diagnosis and follows up. We found higher CT score in ICU patients than non-ICU patients. Previous studies reported higher CT score in severe patients compared to non-severe patients [30,31]. Our results confirmed these studies. The AUC, NPV and PPV of CT score were 0.83, 0.97 and 0.33 in the discrimination of patients with ICU requirement, respectively. We think that because of the higher negative predictive value, CT score can be used to rule out of severe cases as well as procalcitonin, D-Dimer, CRP, glucose, and LDH. CT systems are expensive, and require technical expertise and stuff. Therefore the CT system is not universally. In the present study, CT score was found highly correlated with fibrinogen and CRP. Besides, we found statistically significant difference between patients with normal chest CT findings and patients with abnormal chest CT findings including GGO, consolidation and crazy paving pattern (CPP) in terms of the serum levels of CRP and fibrinogen. GGO, consolidation and CPP are commonly seen findings in chest CT of patients with COVID-19 [32]. Yuan et al. [33] reported that the frequency of consolidations was higher in the fatal cases. Li et al. [34] indicated that the incidence of consolidation, linear opacities and CPP was significantly higher in severe patients than nonsevere patients. Pan et al. [35] showed that combination with diffuse GGO and consolidation, CPP could be an indicator of COVID-19 progression. Accordingly, we think that CRP and fibrinogen can be used to follow up and predict of the lung damages in patients with COVID-19.

In our COVID-19 clinic doctors worked shifts to minimize exposure to the virus. For this reason, an optimization could not be achieved at the order of laboratory tests and therefore some biochemical data could not be extracted in all patients. Secondly, we did not optimize blood sampling time. Thus, results mighty be affected by nutritional status and diurnal variation. The findings of this study have to be seen in the light of these limitations.

In conclusion; CT score, procalcitonin, D-Dimer, CRP, glucose, and LDH can be used to rule out ICU requirement on hospital admission. The cut-off values of procalcitonin, CRP and D-dimer to rule out ICU requirement were within the reference values. Thus, clinicians should be aware of the changes within the reference values for these biomarkers. CT score was found highly correlated with fibrinogen and CRP. Accordingly, we think that fibrinogen and CRP can be used to follow up and predict of the lung damages in patients with COVID-19.

Research funding: None declared.

Author contributions: All authors have accepted responsibility for the entire content of this manuscript and approved its submission.

Competing interest: Authors state no conflict of interest.

\section{References}

1. Paules $\mathrm{Cl}$, Marston HD, Fauci AS. Coronavirus infections-more than just the common cold. J Am Med Assoc 2020;323:707.

2. https://www.who.int/emergencies/diseases/novelcoronavirus-2019.

3. Harapan H, Itoh N, Yufika A, Winardi W, Keam S, Te H, et al. Coronavirus disease 2019 (COVID-19): a literature review.

J. Infect. Public Health 2020;13:667-73.

4. Huang C, Wang Y, Li X, Ren L, Zhao J, Hu Y, et al. Clinical features of patients infected with 2019 novel coronavirus in Wuhan, China. Lancet 2020;395:497-506.

5. Zaim S, Chong JH, Sankaranarayanan V, Harky A. COVID-19 and multiorgan response. Curr Probl Cardiol 2020;45:100618.

6. Baud D, Qi X, Nielsen-Saines K, Musso D, Pomar L, Favre G. Real estimates of mortality following COVID-19 infection. Lancet Infect Dis 2020;20:773.

7. Baker T, Schell CO, Petersen DB, Sawe H, Khalid K, Mndolo S, et al. Essential care of critical illness must not be forgotten in the COVID-19 pandemic. Lancet 2020;395:1253-4.

8. https://sbsgm.saglik.gov.tr/TR,66560/haftalik-rapor-weeklyreport.html.

9. Xie J, Tong Z, Guan X, Du B, Qiu H, Slutsky AS. Critical care crisis and some recommendations during the COVID-19 epidemic in China. Intensive Care Med 2020;46:837-40.

10. Phua J, Weng L, Ling L, Egi M, Lim C-M, Divatia JV, et al. Intensive care management of coronavirus disease 2019 (COVID-19): challenges and recommendations. Lancet Respir. Med 2020;8: 506-17.

11. Wynants L, Van Calster B, Collins GS, Riley RD, Heinze G, Schuit E, et al. Prediction models for diagnosis and prognosis of covid-19: systematic review and critical appraisal. BMJ 2020:m1328. https://doi.org/10.1136/bmj.m1328.

12. Wu R, Wang L, Kuo H-CD, Shannar A, Peter R, Chou PJ, et al. An update on current therapeutic drugs treating COVID-19. Curr. Pharmacol Rep. 2020:1-15.

13. Bohn MK, Lippi G, Horvath A, Sethi S, Koch D, Ferrari M, et al. Molecular, serological, and biochemical diagnosis and monitoring of COVID-19: IFCC taskforce evaluation of the latest evidence. Clin Chem Lab Med 2020;58:1037-52.

14. Mehrabi S, Fontana S, Mambrin F, Nguyen HQ, Righi E, Tacconelli E, et al. Pitfalls of computed tomography in the coronavirus 2019 (COVID-19) era: a new perspective on ground-glass opacities. Cureus 2020;12:e8151. 
15. https://hsgm.saglik.gov.tr/tr/yayinlarimiz/rehberler.html.

16. Henry BM, de Oliveira MHS, Benoit S, Plebani M, Lippi G. Hematologic, biochemical and immune biomarker abnormalities associated with severe illness and mortality in coronavirus disease 2019 (COVID-19): a meta-analysis. Clin Chem Lab Med 2020;58:1021-8.

17. Chen N, Zhou M, Dong X, Qu J, Gong F, Han Y, et al. Epidemiological and clinical characteristics of 99 cases of 2019 novel coronavirus pneumonia in Wuhan, China: a descriptive study. Lancet 2020;395:507-13.

18. Lippi G, Plebani M. Laboratory abnormalities in patients with COVID-2019 infection. Clin Chem Lab Med 2020;58:1131-4.

19. Huang C, Wang Y, Li X, Ren L, Zhao J, Hu Y, et al. Clinical features of patients infected with 2019 novel coronavirus in Wuhan, China. Lancet 2020;395:497-506.

20. Zhou F, Yu T, Du R, Fan G, Liu Y, Liu Z, et al. Clinical course and risk factors for mortality of adult inpatients with COVID-19 in Wuhan, China: a retrospective cohort study. Lancet 2020;395: 1054-62.

21. Zhang J, Dong X, Cao Y, Yuan Y, Yang Y, Yan Y, et al. Clinical characteristics of 140 patients infected with SARS-CoV-2 in Wuhan, China. Allergy 2020;75:1730-41.

22. Lippi G, South AM, Henry BM. Electrolyte imbalances in patients with severe coronavirus disease 2019 (COVID-19). Ann. Clin. Biochem. Int J Lab Med 2020;57:262-5.

23. Cheng Y, Luo R, Wang K, Zhang M, Wang Z, Dong L, et al. Kidney disease is associated with in-hospital death of patients with COVID-19. Kidney Int 2020;97:829-38.

24. Gulhar R, Ashraf MA, Jialal I. Physiology, acute phase reactants. StatPearls 2020.

25. Bonetti G, Manelli F, Patroni A, Bettinardi A, Borrelli G, Fiordalisi $G$, et al. Laboratory predictors of death from coronavirus disease 2019 (COVID-19) in the area of Valcamonica, Italy. Clin Chem Lab Med;58:1100-5. https://doi. org/10.1515/cclm-2020-0459.
26. Chee YJ, Ng SJH, Yeoh E. Diabetic ketoacidosis precipitated by Covid-19 in a patient with newly diagnosed diabetes mellitus. Diabetes Res Clin Pract 2020;164:108166.

27. Li J, Wang X, Chen J, Zuo X, Zhang H, Deng A. COVID-19 infection may cause ketosis and ketoacidosis. Diabetes Obes Metabol 2020;22:1935-41.

28. Ren H, Yang Y, Wang F, Yan Y, Shi X, Dong K, et al. Association of the insulin resistance marker TyG index with the severity and mortality of COVID-19. Cardiovasc Diabetol 2020;19:58.

29. Pu LJ, Shen Y, Lu L, Zhang RY, Zhang Q, Shen WF. Increased blood glycohemoglobin A1c levels lead to overestimation of arterial oxygen saturation by pulse oximetry in patients with type 2 diabetes. Cardiovasc Diabetol 2012;11:110.

30. Li K, Chen D, Chen S, Feng Y, Chang C, Wang Z, et al. Predictors of fatality including radiographic findings in adults with COVID-19. Respir Res 2020;21:146.

31. Francone M, lafrate F, Masci GM, Coco S, Cilia F, Manganaro L, et al. Chest CT score in COVID-19 patients: correlation with disease severity and short-term prognosis. Eur Radiol 2020;30:6808-17.

32. Ye Z, Zhang Y, Wang Y, Huang Z, Song B. Chest CT manifestations of new coronavirus disease 2019 (COVID-19): a pictorial review. Eur Radiol 2020;30:4381-9.

33. Yuan M, Yin W, Tao Z, Tan W, Hu Y. Association of radiologic findings with mortality of patients infected with 2019 novel coronavirus in Wuhan, China. PLoS One 2020;15:e0230548.

34. Li K, Wu J, Wu F, Guo D, Chen L, Fang Z, et al. The clinical and chest CT features associated with severe and critical COVID-19 pneumonia. Invest Radiol 2020;55:327-31.

35. Pan F, Ye T, Sun P, Gui S, Liang B, Li L, et al. Time course of lung changes at chest $\mathrm{CT}$ during recovery from coronavirus disease 2019 (COVID-19). Radiology 2020;295:715-21.

Supplementary Material: The online version of this article offers supplementary material (https://doi.org/10.1515/tjb-2020-0359). 